\title{
Toxic cyanobacteria and cyanotoxins in European waters - recent progress achieved through the CYANOCOST Action and challenges for further research
}

\author{
Jussi Meriluoto, ${ }^{1,2 *}$ Ludek Blaha, ${ }^{3}$ Gorenka Bojadzija, ${ }^{4}$ Myriam Bormans, ${ }^{4}$ Luc Brient,${ }^{4}$ Geoffrey A. Codd $, 5,6$ \\ Damjana Drobac, ${ }^{2}$ Elisabeth J. Faassen, ${ }^{7}$ Jutta Fastner, ${ }^{8}$ Anastasia Hiskia, ${ }^{9}$ Bastiaan W. Ibelings, ${ }^{10}$ Triantafyllos Kaloudis, ${ }^{11}$ \\ Mikolaj Kokocinski, ${ }^{12}$ Rainer Kurmayer, ${ }^{13}$ Dijana Pantelić, ${ }^{2}$ Antonio Quesada, ${ }^{14}$ Nico Salmaso, ${ }^{15}$ Nada Tokodi, ${ }^{2}$ \\ Theodoros M. Triantis, ${ }^{9}$ Petra M. Visser, ${ }^{16}$ Zorica Svirčev ${ }^{1,2}$
}

\begin{abstract}
${ }^{1}$ Biochemistry, Faculty of Science and Engineering, Åbo Akademi University, Tykistökatu 6A, 20520 Turku, Finland; ${ }^{2}$ Laboratory for Paleoenvironmental Reconstruction, Faculty of Sciences, University of Novi Sad, Trg Dositeja Obradovica 2, 21000 Novi Sad, Serbia; ${ }^{3}$ RECETOX, Faculty of Science, Masaryk University, Kamenice 5, CZ62500 Brno, Czech Republic; ${ }^{4}$ UMR ECOBIO 6553 CNRS Université de Rennes, 1 Campus de Beaulieu, Rennes, France; ${ }^{5}$ Biological and Environmental Sciences, University of Stirling, Stirling FK9 4LA, Scotland; ${ }^{6}$ College of Life Sciences, University of Dundee, Dow Street, Dundee DD1 5EH, Scotland; ${ }^{7}$ Aquatic Ecology \& Water Quality Management Group, Wageningen University, P.O. Box 47, Wageningen 6700 DD, The Netherlands; ${ }^{8}$ Section Drinking Water Resources and Water Treatment, German Environment Agency, Corrensplatz 1, 14195 Berlin, Germany; ${ }^{9}$ Institute of Nanoscience \& Nanotechnology, National Center for Scientific Research “DEMOKRITOS”, Neapoleos 10, Ag. Paraskevi 153 10, Athens, Greece; ${ }^{10}$ Department F.-A. Forel for Environmental and Aquatic Sciences and Institute for Environmental Sciences, University of Geneva, 66 Boulevard Carl-Vogt, 1211 Geneva 4, Switzerland; ${ }^{11}$ Department of Water Quality Control, Athens Water Supply and Sewerage Company, Laodikias 29, Athens, Greece; ${ }^{12}$ Department of Hydrobiology, Faculty of Biology, Adam Mickiewicz University, Wieniawskiego 1, 61-712 Poznań, Poland; ${ }^{13}$ Research Institute for Limnology, University of Innsbruck, Mondseestrasse 9,

5310 Mondsee, Austria; ${ }^{14}$ Department of Biology, Universidad Autónoma de Madrid, 28049 Madrid, Spain; ${ }^{15}$ Department of Sustainable Agrosystems and Bioresources, Research and Innovation Centre, Fondazione Edmund Mach, Via E. Mach 1, 38010 San Michele all'Adige, TN, Italy; ${ }^{16}$ Department of Aquatic Microbiology, Institute for Biodiversity and Ecosystem Dynamics, University of Amsterdam, P.O. Box 94248, 1090 GE Amsterdam, The Netherlands

*Corresponding author: jussi.meriluoto@abo.fi
\end{abstract}

\begin{abstract}
This review aims to summarise the outcomes of some recent European research concerning toxic cyanobacteria and cyanotoxins, with an emphasis on developments within the framework of the CYANOCOST Action: COST Action ES1105, Cyanobacterial Blooms and Toxins in Water Resources: Occurrence, Impacts and Management. Highlights of the Action include phycological and ecological studies, development of advanced techniques for cyanotoxin analysis, elucidation of cyanotoxin modes of action, management techniques to reduce cyanobacterial mass development, and research on methods and practices for cyanotoxin removal during drinking water treatment. The authors have identified a number of gaps in knowledge. Proposed directions for future research on toxic cyanobacteria and cyanotoxins are also discussed.
\end{abstract}

Key words: Cyanobacteria; cyanotoxins; Europe; trends; gaps of knowledge.

Received: 29 November 2016. Accepted: 7 March 2017.

\section{INTRODUCTION}

Toxigenic cyanobacteria are one of the major health risks associated with water resources, in Europe and beyond. Cyanobacteria can produce a wide range of potent toxins (cyanotoxins) with adverse health effects on humans and animals exposed e.g., via drinking water, aquaculture and recreation.

The hepatotoxic peptide toxins (microcystins: MCs) occur annually in most countries and this cyanotoxin family is considered a major concern in the European context. MCs have been identified as undisputed health hazards by the World Health Organization (WHO). Emerging cyanotoxins are also of concern in Europe; e.g., cylindrosper- mopsin (CYN) which was viewed as being limited to (sub)tropical waters but has been recently found in several European countries. It has been postulated that such emerging cyanotoxins could be related to invasive cyanobacterial species that are colonizing European waters. Recent research has also demonstrated a definite relationship, on a global scale, between temperature and the dominance of cyanobacteria in water bodies (O’Neil et al., 2012).

Advanced methods have already been developed in European laboratories to detect, identify and quantitate cyanotoxins. Although ISO 20179:2005 introduced a standard method to determine MCs, other methods for cyanotoxin analysis are not harmonized across Europe. Techniques including liquid chromatography - mass spec- 
trometry (LC-MS) have enabled cyanotoxin detection and identification at very low concentrations. Rapid immunoassay methods, for on-site use, are also being developed in Europe, and merit dissemination with verification, as kits, to increase capabilities in regions without hightechnology resources.

Multiple techniques (proactive and reactive) have already been used to control cyanobacterial blooms in Europe, with varying degrees of success. Control measures for cyanobacterial and cyanotoxin management have been developed, and these range from catchment and basin-scale management, to drinking water treatment methods for the removal of cyanobacterial cells and cyanotoxins, including sorption, filtration and advanced oxidation processes.

An important part of almost any research is end-user involvement. This is especially true in research concerning public health questions including the research activities related to CYANOCOST.

\section{OCCURRENCE OF CYANOBACTERIA AND CYANOTOXINS, AND METHODS FOR MONITORING AND ANALYSIS}

The continuing eutrophication of many aquatic ecosystems and water resources in Europe is causing concern because the deterioration of water quality and potentially toxic blooms of cyanobacteria threaten human and animal health. Throughout the CYANOCOST Action it was shown that toxic cyanobacteria and various cyanotoxins are commonly found in all parts of Europe. However, it is difficult to make firm conclusions about any trends in the occurrence of toxic cyanobacteria and cyanotoxins as monitoring has only recently been introduced in some parts of Europe. There has been very little systematic cyanotoxin monitoring of waters in most countries as the cyanotoxin analyses have been primarily carried out by academic partners involved in specific research projects or, in some cases, by public or private water utilities abstracting water from potentially high-risk sources. It is also likely that there has been a certain bias towards the cyanotoxins for which the analytical methods are more widely established, i.e. for the MCs, and the full spectrum of cyanotoxins present in Europe still remains to be comprehensively assessed. What can be concluded without doubt is that those laboratories that have been involved in cyanotoxin analyses for a longer time (some since the 1980s) continue to find MCs in many water environments monitored since that time. In addition, further cyanobacterial hazards (invasive species and emerging/less-studied toxins) are being discovered. The joint activity of CYANOCOST and the NETLAKE COST Action (ES1201), the European Multilake Survey (EMLS) conducted in 2015 will be able to provide a snapshot of the cyanobacterial/cyanotoxin situation in a wide range of Eu- ropean waters when the analytical work concentrated in selected laboratories has been finished. It would be highly desirable to be able to continue and expand the monitoring activities initiated within the EMLS and thus get a clearer picture of any trends in cyanotoxin occurrence and abundance in Europe.

Hepatotoxic MCs appear to be the most common and to have the greatest known impacts on human health and activities among the known cyanotoxins in aquatic ecosystems including lakes and rivers across Europe. Major producers of MCs include cyanobacteria from the genus Microcystis and members of other cyanobacterial genera including Planktothrix, Nostoc, Anabaena/Dolichospermum and Anabaenopsis (Merel et al., 2013a, 2013b; Bernard et al., 2017). Nodularin (NOD) hepatotoxins are mostly known from the Baltic Sea. However, recently nodularin was found also in aquatic ecosystems in Turkey (Mazur-Marzec et al., 2013; Sahindokuyucu Kocasari et al., 2015). Moreover, Nodularia spumigena Mertens ex Bornet \& Flahault, a NOD-producer, was recently observed not only in brackish waters but also in freshwater lakes (Akcaalan et al., 2009).

Acutely-acting neurotoxins are much less common than hepatotoxins but are still found in a large variety of water ecosystems. Anatoxin-a (ANTX-a) and/or homoanatoxin-a (hANTX-a) have been detected in lakes and rivers in the UK, Ireland, France, Netherlands, Germany, Italy, Denmark, Portugal, and Poland (Edwards et al., 1992; Furey et al., 2003; Gugger et al., 2005; Messineo et al., 2009; Osswald et al., 2009; Ballot et al., 2010; Faassen et al., 2012b; Kobos et al., 2013). These toxins are associated with several cyanobacteria including, among others, species of Anabaena, Dolichospermum and Aphanizomenon (for an updated list see Bernard et al., 2017). A less toxic analogue, dihydroanatoxin-a was isolated from different strains of Oscillatoria sp., Phormidium sp. and Cylindrospermum stagnale Bornet \& Flahault (Méjean et al., 2014). Evidence for the potent acetylcholinesterase inhibitor anatoxin-a(S) (Onodera et al., 1997) has been found more rarely in Europe: to date, in Denmark (Henriksen et al., 1997) and Scotland (Devic et al., 2002). Saxitoxins (STXs) have also been rarely reported from European freshwaters. These potent neurotoxins were observed in several countries including France, Finland, and Spain associated mostly with the occurrence of Aphanizomenon spp. (Rapala et al., 2005; Ledreux et al., 2010; Cirés et al., 2014).

The cytotoxin and genotoxin CYN was until recently only known from warmer regions. During the last decade, it has been detected in several European countries. A further discussion about CYN is found later in this section.

In addition to these three major groups of cyanotoxins, i.e., hepatotoxins, neurotoxins and cytotoxins, there is abundant toxicological evidence for further unidentified 
cyanobacterial bioactive/toxic compounds in aquatic ecosystems in Europe (Elersek et al., 2017). Besides new toxins and indications of a widening occurrence of known toxins, future research may reveal new environments affected with toxic/noxious cyanobacteria and their toxins. Additional threats to aquatic ecosystems may be caused by alien and invasive species that are expanding their geographical range (Kokociński et al., 2017). Cylindrospermopsis raciborskii (Woloszynska) Seenayya \& Subba Raju is an example of a cyanobacterium that has increased its distribution from tropical and subtropical regions towards the temperate zone where it is now widespread. This species is known for the production of CYN and STXs in warmer regions but, so far, this was not confirmed in Europe. Recent studies, however, revealed the ability of this cyanobacterium to produce unknown metabolites causing toxic effects (Poniedziałek et al., 2015). Among other alien species that occur more and more frequently in Europe are Chrysosporum bergii (Ostenfeld) E. Zapomělová, O. Skácelová, P. Pumann, R. Kopp \& E. Janeček, Chrysosporum ovalisporum (Forti) E. Zapomělová, O. Skácelová, P. Pumann, R. Kopp \& E. Janeček, and Sphaerospermopsis aphanizomenoides (Forti) Zapomělová, Jezberová, Hrouzek, Hisem, Reháková \& Komárková. These are known CYN-producers (with the exception of the last one the toxicity of which remains debatable) (Quesada et al., 2006; Kaštovskỳ et al., 2010; Koreivienè and Kasperovičenè, 2011) and an increasing distribution and abundance of these species may contribute to additional toxic stress in European freshwaters.

Already before 2012, i.e., the start of the CYANOCOST Action, MCs and ANTXs had been involved in poisoning episodes affecting animal and/or human health in Europe but no health effects caused by CYN had been observed/reported. The (apparent or true) increasing occurrence of CYN in Europe is likely to change this picture, and health effects caused by CYN can be expected especially in Southern and Central Europe, the source of most of the reports concerning CYN. In addition, there have been cases of reported poisonings in European waters where unknown/new cyanotoxins have been inferred but a more exact identification was lacking.

Health effects and poisoning episodes related to cyanotoxin-contaminated drinking and recreational waters were documented during the lifetime of CYANOCOST. However, the number of reported cases was relatively low. This may indicate an increased awareness and implementation of better monitoring and management systems for toxic cyanobacteria. There have also been improvements in analytical capability for cyanotoxin detection in many countries, partly thanks to increased international collaboration and the spreading of know-how. A possible reason for fewer reports in the scientific literature may be the fact that it is increasingly difficult to get cyanotoxin episodes published unless something really dramatic or novel is involved.

However, as shown by the Užice case reported here (see Fate, impact and health effects), recognition of the occurrence and impacts of toxigenic cyanobacteria remains inadequate in Europe, and cyanotoxins continue to cause serious health effects, not only in individuals but also at the population level. The lack of international and national regulatory guidelines for most cyanotoxins in drinking water is a serious problem which needs to be addressed urgently and which was highlighted also in the Užice case. While modern sensitive analytical equipment can relatively easily comply with the most demanding monitoring needs, the lack of regulatory guidelines for most cyanotoxins is likely to give the cyanotoxins a lower priority in monitoring. Also, the lack of commercial analytical reference materials is problematic.

Among the cyanotoxins, there are two toxins of growing importance in European waters and elsewhere: CYN and $\beta$ - $N$-methylamino-L-alanine (BMAA). CYN is a potent cytotoxic and genotoxic cyanotoxin initially detected in Australia (Ohtani et al., 1992; Saker and Neilan, 2001). Later, it was reported in New Zealand (Stirling and Quilliam, 2001), Thailand (Li et al., 2001) and other tropical and subtropical regions (Rzymski and Poniedziałek, 2014). CYN was named after the first identified producer $C$. raciborskii being involved in human poisoning and an outbreak of hepatoenteritis among the aboriginal community in Australia. Nowadays CYN has been detected more widely and there are more than 12 known producers (de la Cruz et al., 2013). In Europe, this toxin was first reported in Germany in 2000 in two shallow lakes in the eastern part of Brandenburg (Fastner et al., 2003). Further, in Hungary in 2002 (Kiss et al., 2002), Italy and Spain in 2004 (Manti et al., 2005; Quesada et al., 2006), Finland, France, the Czech Republic and Poland in 2006 (Spoof et al., 2006; Bláhová et al., 2009; Brient et al., 2009; Kokociński et al., 2009). In Europe, cyanobacteria capable of producing CYN have most often been found in the genera Aphanizomenon, Anabaena/Dolichospermum, Chrysosporum and Oscillatoria (Kokociński et al., 2013; Rzymski and Poniedziałek, 2014; Bernard et al., 2017). More potential producers of CYN have been revealed lately including Dolichospermum mendotae (W. Trelease) P. Wacklin, L. Hoffmann \& J. Komárek in Turkey and the terrestrial cyanobacterium Hormoscilla pringsheimii Anagnostidis \& Komárek (Akcaalan et al., 2014; Bohunická et al., 2015). Moreover, Gkelis and Zaoutsos (2014) for the first time reported CYN and a C. raciborskii bloom producing STX in Greece but a definitive identification of the CYN producer could not be made. In Europe, in contrast to warmer regions, thus only non-CYN producing populations of $C$. raciborskii have been so far identified except for a recent report from Serbia (Đorđević et al., 2015). The latter observation however is disputable 
as no studies on isolated cultures of this cyanobacterium were performed. Complementary studies have been recently conducted on the toxicity of CYN (Guzmán-Guillén et al., 2015; Sierosławska et al., 2015;), mechanisms of toxicity (Poniedziałek et al., 2014), biodegradation (Dziga et al., 2016) and biological role and allelopathy (B-Béres et al., 2015). These works have contributed valuable knowledge on these aspects but at the same time have revealed many gaps in understanding of the role(s) of CYN in aquatic ecosystems and its impact on their functioning (Sukenik et al., 2015). Future studies are needed also on factors regulating biosynthesis of this toxin, its biodegradation by bacterial communities and other potential producers including benthic and terrestrial cyanobacteria. 7-deoxy-CYN and 7-epi-CYN are naturally occurring congeners of CYN (reviewed by de la Cruz et al., 2013). Different Aphanizomenon sp. strains obtained from German lakes were confirmed as producers of 7-deoxy-CYN while strains of Chr. ovalisporum and C. raciborskii are known to produce also 7-epi-CYN (Rzymski and Poniedziałek, 2014; Cirés and Ballot, 2016). Recently two new analogs, 7-deoxy-desulfo-CYN and 7-deoxy-desulfo-12-acetylCYN, were isolated from a Thai strain of C. raciborskii (Wimmer et al., 2014).

In the period of 2012-2016, important steps towards a better understanding of the presence of the neurotoxin BMAA in surface waters have been made. The presence of BMAA in a diversity of cyanobacterial strains was first described in 2005 (Cox et al., 2005), and subsequent studies reported conflicting results (reviewed by Faassen, 2014). Differences in analytical approaches were assumed to be one of the main causes of these diverging results, and in 2012, two independent studies recommended suitable analytical methods for BMAA determination (Cohen 2012; Faassen et al., 2012a). Although some analytical challenges remain (Lage et al., 2015; Faassen et al., 2016), a more consistent picture of the presence of BMAA in aquatic systems appears when only the studies that used recommended analytical approaches (Cohen, 2012; Duncan, 2012; Faassen et al., 2012a) are considered (Faassen, 2014).

In Europe, BMAA has frequently been detected in aquatic organisms sometimes intended for human consumption, including fish, molluscs and other seafood, at or below the low $\mu \mathrm{g} \mathrm{g}^{-1}$ DW level (Faassen, 2014; Jiang et al., 2014b; Réveillon et al., 2016b). Similar levels are found in some phytoplankton samples or strains (Faassen 2014). While at first cyanobacteria were hypothesised to be the source of BMAA in aquatic systems, BMAA has now also been detected in diatoms (Jiang et al., 2014a; Lage et al., 2015; Réveillon et al., 2015), and a diatom strain has been shown to contain BMAA during different growth phases (Réveillon et al., 2016a). Recently, a major fraction of BMAA was found to be present in a soluble, bound form in a diversity of samples (Faassen et al., 2016;
Rosén et al., 2016), where traditionally BMAA was considered to be present either as a free molecule or in a protein-associated form (Murch et al., 2004). Only if more consensus is created on the presence of BMAA in aquatic systems, and human exposure levels can be assessed with confidence, will it be possible to determine whether BMAA does indeed play a role in the globally-occurring neurodegenerative diseases Alzheimer's, Parkinsonism and amyotrophic lateral sclerosis, as is currently hypothesized (Bradley and Mash, 2009).

The traditional identification of cyanobacteria has been based on light microscopy and this technique continues to dominate in most laboratories throughout Europe as documented in the recent Handbook of Cyanobacterial Monitoring and Cyanotoxin Analysis (Meriluoto et al., 2017). However, the morphological species concept is changing in the microbial world, and molecular tools are impacting on this regarding cyanobacteria. The rapidly growing body of information from molecular biological studies (see the text about the second handbook later in this section, Kurmayer et al., 2017) is also very useful in distinguishing between potentially toxigenic and non-toxigenic cyanobacterial strains but which may have identical morphological features.

Advances are being made in cyanotoxin screening and trace analysis. Commercial enzyme-linked immunoassays (ELISAs) are being applied for the screening for some cyanotoxins, as are protein phosphatase inhibition assays for the detection of MCs and NODs. However, the need for users to themselves verify the specificity of these methods, taking into account false positives and responses to cyanotoxin detoxification products, is emphasised. The most rapid and dramatic (in terms of sensitivity) advances have been made in instrumental analyses based on liquid chromatography-tandem mass spectrometry (LCMS/MS). LC-MS/MS is extremely well suited for regulatory settings as it can target individual analytes and the methods can be fully validated. In addition, LC-MS can be used simultaneously for several classes of compounds. Zervou et al. (2017) provide a good example of this multitoxin approach where $12 \mathrm{MCs}, \mathrm{NOD}, \mathrm{CYN}, \mathrm{ANTX}-\mathrm{a}$, and the marine algal toxins domoic acid and okadaic acid were concentrated by a dual-cartridge solid-phase extraction procedure and determined in a single LC-MS/MS run. One obvious complication with LC-MS/MS analyses is the need for reference materials which are currently not commercially available for all cyanotoxins.

What has become increasingly evident during the last few years is that various bioassays are still needed in identifying new toxic agents produced by cyanobacteria. New bioassays based on cell lines or invertebrates have almost totally replaced the traditional mouse bioassay which was relied upon in the 1980s when the knowledge about cyanotoxins and their effects on mammalian/human health was 
still developing. Such bioassays can possibly detect novel bioactive, including potentially harmful, compounds. However, the broader application of bioassays in the monitoring of toxic cyanobacteria is still an open issue. The ongoing discussion among scientists and regulators aims to clarify important points such as causality between bioassay responses and toxin concentrations, bioassay specificity, action or regulatory limits, etc.

In the past two decades, molecular biology has provided a major contribution to understanding cyanotoxin biosynthesis pathways (Kurmayer et al., 2017). The elucidation of the pathways of MC and NOD biosynthesis (Tillett et al., 2000; Moffitt and Neilan, 2004) was followed by discovery of the pathways of CYN biosynthesis (Shalev-Alon et al., 2002; Mihali et al., 2008), STX biosynthesis (Kellmann et al., 2008) and ANTX-a biosynthesis (Méjean et al., 2009). In general, cyanotoxin molecules are synthesized by non-ribosomal peptide synthesis (NRPS) partly involving polyketide synthases (PKS) and tailoring enzymes following a thiotemplate mechanism which is widely distributed among bacteria and fungi (Fischbach and Walsh, 2006). Synthesis pathways have been explored by characterizing specific enzymatic steps in vitro (Hicks et al., 2006), by experimental inactivation of core and tailoring enzymatic steps in vivo (Christiansen et al., 2003), and by crystallization of heterologously-expressed enzymes (Mazmouz et al., 2011).

In parallel with gene cluster elucidation: i) various gene loci have been tested for their reliability to indicate the presence of a specific cyanotoxin biosynthesis pathway (Jungblut and Neilan, 2006); and ii) phylogenetic analysis of various gene loci has been used to investigate the inheritance of cyanotoxin biosynthesis pathways (Rantala et al., 2004). This research has revealed specific gene loci indicative of MC/NOD biosynthesis (Rantala et al., 2004), ANTX-a biosynthesis (Rantala-Ylinen et al., 2011), and CYN biosynthesis (Mihali et al., 2008), and preliminary candidate gene loci indicative of STX biosynthesis (Kellmann et al., 2008). Today it is understood that $\mathrm{MC}$ and STX biosynthesis pathways are both ancient and evolved about 2 billion years ago corresponding to the evolution of the heterocytous cyanobacteria as an adaptation to the oxygen-containing atmosphere (Rantala et al., 2004; Murray et al., 2011). Consequently, due to an ancestral common origin for these cyanotoxins (MC/NOD, STX), their present-day production is widely distributed among extant cyanobacteria and is likely to be more so than is currently recognised. This type of phylogenetic analysis has further suggested that, in comparison with horizontal gene transfer events, the vertical inheritance and ongoing cyanotoxin gene cluster loss processes are probably important in explaining the rather patchy distribution among cyanobacterial taxa. Correspondingly, for $\mathrm{CYN}$, phylogenetic congruence with cyanobacterial evo- lution and CYN biosynthesis has been reported (Jiang et al., 2012). For ANTX-a biosynthesis, recent phylogenetic analysis has revealed significant homology within the ANTX-a biosynthesis pathway across cyanobacterial taxa (Brown et al., 2016).

Current understanding of the molecular biology of cyanotoxin biosynthesis has been recently compiled into a molecular tools handbook which contains protocols describing methods to detect and to quantify toxigenic cyanobacteria in aquatic and terrestrial environments and in food supplements (Kurmayer et al., 2017). This compilation contains protocols on sampling and cyanobacterial isolation and identification, and standard protocols on DNA (mRNA) extraction and PCR amplification of gene loci indicative of cyanotoxin biosynthesis. In addition to toxigenic cyanobacterial detection and quantification protocols, methods to analyze the regulation of cyanotoxin synthesis are also included. For quantitative analysis, the techniques used in qPCR have been collected. The compilation also includes traditional microarray and denaturing gradient gel electrophoresis protocols to characterize genetic community/population structure based on cyanotoxin synthesis gene fragments. High-throughput sequencing protocols have been included to aid the investigation of cyanobacterial community composition. Finally, the application of molecular tools in the scientific literature has been collected and reviewed (Kurmayer et al., 2017).

In principal, molecular tools only can reveal the potential for cyanotoxin biosynthesis and cannot provide information about actual toxin concentrations or contents. In general, the scientific experience of the predictability of cyanotoxin occurrence qualitatively and quantitatively in environmental samples based upon the determination of cyanotoxin synthesis genes is still insufficient. Particularly for MC/NOD biosynthesis, efforts have been made to correlate cyanotoxin biosynthesis gene abundance with MC/NOD occurrence and concentrations (Koskenniemi et al., 2007; Okello et al., 2010; Ostermaier and Kurmayer, 2010). In some cases, these efforts did not show the expected correlations and further molecular biological analyses will be needed to understand the relevant influences, for example mobile elements, leading to inactivation (Chen et al., 2016). For CYN, STX and ANTX-a occurrence, the predictability from potential indicative biosynthesis genes is even less explored and considerable further effort will be needed (Savela et al., 2015).

The occurrence of false positives in laboratory and environmental samples has been reported repeatedly and needs clarification. In particular, for CYN, STX and ANTX-a the identification of conserved gene (fragments) parts of the core synthesis pathways is still in progress, and needs to identify indicative gene loci to be either used 
singly or in combination. On the other hand, if genes indicative of the above mentioned cyanotoxin synthesis genes are absent, the occurrence of the corresponding cyanotoxins might be excluded. This approach has been partly successful but again depends on the reliability of genetic indication. Thus, the idea that molecular tools can guide the application of more sophisticated chemical-analytical techniques through the detection of cyanotoxinindicator genes is still under development.

\section{FATE, IMPACT AND HEALTH EFFECTS}

Recent reviews on human and animal health aspects include: a health review chapter (Codd et al., 2017), an epidemiological assessment of cancers in Serbia with reference to cyanobacterial blooms (Svirčev et al., 2014a), a review of production, toxinology and toxicology of the ANTX-a and STX neurotoxins (Testai et al., 2016) and a review on epidemiological investigations on health issues related to cyanotoxins (Svirčev et al., 2017a). Recently reported animal intoxications involving cyanobacterial blooms and cyanotoxins have included dogs in the Netherlands, with hANTX-a (Faassen et al., 2012b) and MC-LR (Lürling and Faassen, 2013) as likely proximal causes. Fish-kills associated with cyanobacterial blooms have continued throughout CYANOCOST, e.g. in Greece and Russia (Kormas KA, Papadimitriou T, Chernova E: personal communications). An ongoing likelihood for the role of additional (or alternative) uncharacterised or novel cyanotoxins of health significance was provided in a further, major fish-kill in Serbia in which candidate cyanotoxins (CYN, STXs, MCs) were not detected although the $C$. raciborskii bloom material was lethal by bioassay using Artemia salina (Svirčev et al., 2016). It is evident that the range of health hazards presented by cyanobacteria and their metabolites is only partially understood. For example, in vitro bioassays have revealed a stimulation of mammalian estrogenic activity by cyanobacterial exudates (Sychrova et al., 2012) and a stimulation of proinflammatory responses by MC-LR; the latter effect not being attributable to the long-known inhibition of protein phosphatases by MCs (Adamovsky et al., 2015). Recognition of the roles of exposure media and routes via which cyanotoxins may present risks to human health has also been increased: one of the first risk assessments of exposure to cyanotoxins from terrestrial sources concerned potential inhalation exposure to airborne MCs from cyanobacterial desert crusts (Metcalf et al., 2012).

The following paragraphs summarise some examples and case studies which have been well documented in Serbia, which is greatly affected by toxic cyanobacterial blooms (Simeunović et al., 2010; Svirčev et al., 2013; Svirčev et al., 2014b). On 14 December 2013, a bloom of Planktothrix rubescens (de Candolle ex Gomont) K. Anagnostidis \& J. Komárek was observed in the Vrutci reservoir which is the drinking water source for the city of Užice, Serbia, where 70,000 inhabitants were potentially exposed to cyanotoxins. The first comprehensive analysis showed the presence of $P$. rubescens in the treated water at about 10,000 cells per litre, and approximately 1000 cells per litre in a sample from the pipedwater network (Institute of Public Health Serbia, 2014). Therefore, from 26 December 2013, the use of tap water for drinking and cooking purposes was prohibited by the Sanitary Inspectorate of the Republic of Serbia. This initially provoked panic among the citizens. However, the situation was manageable and satisfactorily resolved (at least in the short-term). Further analysis showed that the number of $P$. rubescens cells reached as high as 107,900 cells per millilitre in the reservoir (Agency for Environmental Protection, 2013). The MC-LR concentration in a piped-water network sample was below the WHO provisional guideline value $\left(1 \mu \mathrm{g} \mathrm{L}^{-1}\right)$ (Institute of Public Health Serbia, 2014). Later research (Drobac, 2015; Svirčev et al., 2017b) confirmed the toxicity of the cyanobacterial biomass by A. salina bioassay. MCs were detected in the lake water by LC-MS/MS (Drobac, 2015; Svirčev et al., 2017b). MC was also detected in the treated tap water and in fish from the reservoir. Additional investigations in the form of questionnaires, epidemiological studies and analysis of cyanotoxins in frozen fish suggested that cyanobacterial blooms might have occurred in the waterbody considerably earlier than the observed bloom in December 2013. Furthermore, questionnaire and epidemiological studies indicated the occurrence of gastrointestinal and skin diseases, possible as a result of exposure to cyanobacterial blooms from the reservoir Vrutci (Đenić, 2014; Drobac, 2015; Svirčev et al., 2017b).While the Vrutci reservoir continued to bloom, a radical but temporary 'Užice solution' was implemented in order to protect human health, and after 7 February 2014 the abstraction of water from the blooming reservoir was switched to an alternative source, Sušičko vrelo.

The Užice case showed the importance of giving adequate information and advice to the general public. In order to prevent panic and to support the affected population, additional measures should be employed: informative flyers distributed in regions with the problem; daily or weekly updates on the situation; a hotline for the public for further questions and suggestions for dealing with the problem. Also, the value of displaying visible, clear and understandable warnings in areas near blooming waters to inform the public of the problem was emphasised, with examples of their successful use in several other countries. The importance of contingency planning, including the prior preparation of warning materials in anticipation of cyanobacterial bloom events was also stressed. 


\section{PREVENTION AND CONTROL MEASURES}

Prevention and control measures which could be used to combat toxic cyanobacteria and cyanotoxins have been addressed by some recent European research. The Special Issue edited by Visser et al. (2016b) "Cyanobacterial blooms. Ecology, prevention, mitigation and control" in the journal Aquatic Ecology compiles a variety of methods that can be used by water managers to control cyanobacteria in lakes and reservoirs. It provides a state of the art overview on prevention, control and mitigation methods for cyanobacterial blooms.

The basis of lake management aiming to reduce cyanobacterial blooms is a comprehensive system analysis which assesses all point and non-point sources of nutrient loading in relation to lake characteristics including morphology, nutrient concentrations and retention times. This multiple approach helps to define the best method to manage cyanobacteria as detailed by Stroom and Kardinaal (2016). In addition, for an effective implementation of control measures in lakes, these should be preferably developed in collaboration with stakeholders and the citizens in a socio-ecological systems approach (Van Dolah et al., 2016).

The most effective and sustainable way to prevent cyanobacterial blooms is by a strong reduction of the inlake nutrient concentration. This comprises both the reduction of the nutrient load from the catchment (Hamilton et al., 2016) and the inflows to the waterbody (Fastner et al., 2016). If internal loading is substantial, hypolimnetic aeration (Bormans et al., 2016), dredging or sediment capping (Douglas et al., 2016) can reduce the release of phosphorus from the sediment. Nevertheless, changes in chlorophyll and abundance of cyanobacteria in lakes where phosphorus in the inflow was reduced show that it may take years before the phytoplankton responds, depending largely on the extent of the decrease in the nutrient load achieved (Fastner et al., 2016). To overcome cyanobacterial problems in these intervening years, or in cases where sufficient reduction of nutrient loading is too costly or not feasible, control and mitigation measures can be used.

The effectiveness of control measures depends on lake characteristics including trophic state, depth and retention time, but also on the cyanobacterial species that bloom in the lake. Various cyanobacterial groups have different key functional traits which make them sensitive to certain control measures while being insensitive to others (Mantzouki et al., 2016). The requirements and limits of the different methods are summarized by Ibelings et al. (2016) and will be briefly listed here. Artificial mixing can be a good technique to reduce cyanobacterial blooms in relatively deep systems $(>15 \mathrm{~m})$ if the aeration system is well distributed in the lake and strong enough to keep cyanobacterial colonies entrained in the turbulent flow (Visser et al., 2016a). Cases in which artificial mixing was applied in a way that did not meet these criteria were unsuccessful in reducing cyanobacterial biomass. Furthermore, the technique works best for buoyant colony-forming cyanobacteria like Microcystis. If mixing is intermittently applied, the technique can also be successful for filamentous cyanobacteria including Planktothrix and Cylindrospermopsis (Antenucci et al., 2005). Decreasing the retention time in a lake can reduce the cyanobacterial biomass if the flushing rate is higher than the growth rate of the cyanobacteria and can thus apply for all cyanobacterial species as documented e.g. for Microcystis (Bowling and Baker, 1996; Ibelings et al., 1998; Verspagen et al., 2006) and Dolichospermum (Webster et al., 2000; Mitrovic et al., 2011). Biomanipulation can be successful in lakes where the external and internal loading have been reduced as it can promote the development of submerged macrophytes and help to move from a turbid state to a clear water state (Noordhuis et al., 2016; Triest et al., 2016). This holds true for water-level management (Bakker and Hilt, 2016). Cyanocides can also be used to reduce the cyanobacterial biomass regardless of the cyanobacterial species. Matthijs et al. (2016) discussed the application of conventional and new cyanocides in drinking water reservoirs and bathing waters. Especially, hydrogen peroxide appears to be a promising substance for bloom mitigation since cyanobacteria typically show a higher sensitivity to hydrogen peroxide than other groups of aquatic biota. This control agent does not leave any harmful residuals due to its breakdown into oxygen and water, and cyanotoxins degrade rapidly in the treated lakes. There are several further measures that can help in the control of cyanobacteria as discussed by Stroom and Kardinaal (2016). However, several of the commercially offered endof-pipe techniques should be considered with caution as controlled tests with these techniques were often not very promising (Lürling et al., 2016). Mitigation techniques including harvesting of scums, shifting the intake-depth in drinking-water reservoirs, deployment of bubble screens or the selective withdrawal of hypolimnetic waters may be used when water quality improvement is urgent for either drinking or recreational use of water. A ban on swimming or bathing may further reduce the risks associated with cyanobacterial bloom exposure at recreational sites.

Future developments in lake management should aim for clearer guidance in the selection procedure from the suite of available methods, optimization and sustainability of methods and further research into the efficacy and sideeffects of the methods. Furthermore, an overview of investments, economic depreciation over time and annual running and maintenance costs will be important elements in the most (cost) effective selection of measures. Method selection should also pay attention to the carbon footprint of the different methods (e.g., energy use).

There are several conventional and advanced options 
available for the removal/detoxification of cyanotoxins during drinking water treatment (Hiskia et al., 2017). Physical treatment methods can remove cyanotoxins fully or partly from contaminated water. As their aim is the separation of toxins as intact molecules, further processing for the management of the resulting waste is also required. Among these methods, adsorption by activated carbon, either as granular activated carbon (GAC) or powdered activated carbon (PAC), has been reported to be effective for the removal of several dissolved cyanotoxins. The amount and nature of natural organic matter (NOM) in water greatly influences the adsorption and capacity of activated carbon for cyanotoxins. NOM is typically present at higher concentrations than cyanotoxins and competes for active sites on the sorbent material. Activated carbon technologies may also be combined with biological or membrane technologies to create integrated methods. Reverse osmosis and nano-filtration membranes have been tested for MC removal. Although efficient, the above technologies should be evaluated in terms of the operational costs and engineering considerations (Antoniou et al., 2014).

Chemical oxidation processes are a promising additional treatment option due to the potential for complete destruction of cyanotoxins, transformation to less toxic by-products and even complete mineralization (Sharma et al., 2012). On the other hand, oxidants have been found to lyse cyanobacteria, which may release toxins. It is therefore recommended that coagulation or other separation procedures be applied to remove whole cells and to minimise cyanobacterial cell disruption before oxidation.

Although studies have been carried out mainly with MCs, all conventional oxidation processes (ozonation, chlorination, oxidation with permanganate) can degrade cyanotoxins in water. Among them, ozone seems to be the most effective for MC destruction, reacting preferentially with their double bonds. The ability of ozone to oxidize the Adda moiety, which is linked to the toxic properties of MCs, makes treatment with ozone a very promising water detoxification technology for these contaminants. Ozone has also been found to be effective for the destruction of ANTX-a and CYN, although it is less effective with STX (Newcombe, 2002).

Chlorination is also an option for the degradation of MCs and CYN in water, but its efficiency depends on operational parameters, including the nature of the chlorine compounds used. Chlorine-based weaker oxidants (and disinfectants) including chlorine dioxide and chloramines have been found to be ineffective for cyanotoxin degradation. Contrary to the above, ANTX-a has been shown to be quite stable upon chlorination (Sklenar et al., 2016).

Permanganate reacts differently with each group of cyanotoxins. It has high reactivity with most MC variants examined and inactivates Microcystis aeruginosa cells without significant release of MCs after treatment. The low release of cyanotoxins during treatment in combination with its effectiveness to inactivate $M$. aeruginos $a$ and oxidize MCs makes permanganate a potential oxidant for their elimination in drinking water treatment (Sharma et al., 2012). Permanganate is also very reactive with ANTX-a, with $\mathrm{pH}$ playing an important role in the process (Ho et al., 2009), while it is not effective with CYN (Rodriguez et al., 2007).

The reactivity of MCs towards different conventional oxidants is strongly affected by water quality parameters including $\mathrm{pH}$, dissolved organic carbon (DOC) and oxidant dose. Although there is a general trend for cyanotoxins oxidation (ozone $>$ permanganate $>$ chlorine $>>>$ chlorinebased oxidants), the selection of the appropriate oxidant should be assessed for each particular source of water.

Advanced Oxidation Processes (AOPs) are generally more effective in degrading cyanotoxins than conventional oxidation processes since they generate hydroxyl radicals, which react rapidly with all of the groups of cyanotoxins investigated with high second order reaction rate constants. Although the detoxification of water and complete mineralization of cyanotoxins can also be achieved by AOPs, the roles of water quality parameters (e.g., DOC) have to be taken into account. The presence of inorganic and organic water constituents often inhibits the degradation of target pollutants through radical scavenging mechanisms resulting in lower degradation rates. Overall, while there are promising results in removing cyanotoxins using AOPs under laboratory conditions, scale-up studies are needed before these methods are considered as economically feasible and practical sustainable alternatives in water treatment facilities (He et al., 2012; Fotiou et al., 2016).

In conclusion, effective water treatment strongly depends on both water quality parameters and treatment options. It is recommended that water utilities examine all available alternatives and develop a clear set of goals according to their needs and the expected investment and operational costs before applying measures for cyanotoxin treatment at their facilities.

\section{END-USER AND OUTREACH TOOLS, MATERIALS AND PRODUCTS}

While CYANOCOST has not been the first network focusing on toxic cyanobacteria and cyanotoxins, it is deemed to be the network that has actively involved the highest number of countries as well as reaching the most researchers and other stakeholders. This part of the review concentrates solely on the outreach tools of the CYANOCOST Action as the different approaches taken by the Action can serve as an excellent model for similar programmes.

When the CYANOCOST Action was planned, it was understood that one of the main objectives of the proposal 
should be the dissemination of the results of the Action throughout the EU and neighbouring countries. The proponents perceived that the cyanotoxin problem in Europe was widespread but that different countries and regions had very different management and control mechanisms and policies in place, ranging from extremely low levels of control, to very sophisticated intensive management tools. Awareness of the water and health authorities of the problem varied from country to country.

The CYANOCOST Action turned out to be a useful vehicle to extend and increase recognition and awareness of the occurrence of cyanobacteria and cyanotoxins, and to make key management tools more widely available to counteract the adverse effects of cyanobacterial mass growths and cyanotoxins. Dissemination of the scientific and practical results of the CYANOCOST Action needed to target a broad range of audiences and end-users. These included: i) researchers, especially young ones, from diverse disciplines: analytical chemists, (molecular) biologists, ecologists, toxicologists, water engineers; ii) the drinking water industry, especially managers involved in water quality control; iii) recreational water facility managers; iv) aquaculture and agriculture enterprises and managers; v) environmental laboratories, both public and private; vi) equipment and material designers and manufacturers; vii) public health and clinical professionals, water district authorities and organizations; viii) environmental and public health policy makers at national and European level; ix) non-governmental organizations active in environmental public awareness; $(\mathrm{x})$ regional and national water sports organizations; and xi) the general public.

What are the relevant approaches to be considered for a successful dissemination in a scientific project? As exemplified above, CYANOCOST needed to engage a large number of end-users and stakeholders. The value of different dissemination approaches using databases, webpages, social media, flyers, specialized books, special issues in scientific journals, training schools and shortterm scientific missions (STSMs) were considered within the Action, and these approaches were developed, based on responses from the Action participants and stakeholders. The approaches taken by the Action are described in the following text as examples that can be generalised and used in similar projects.

A Europe-wide rolling database (https://sites.google. com/site/cyanocost/) which was an extension of the 2005 UNESCO CYANONET database (Codd et al., 2005) was developed within the Action. The CYANOCOST database contains useful contacts of researchers, organizations, companies involved in this field, with extended profiles, expertise, publications, projects, collaborations and contact details. Links to national risk management policies in use in Europe and in neighbouring states, including guidelines and legislation, are included. The database has been origi- nally designed for use by CYANOCOST participants only but it is expected to be made freely available for the public. In addition to this Europe-wide database, a freely-accessible local database, the Serbian Cyanobacterial Database (https://cloud.pmf.uns.ac.rs/index.php/s/v6tErVCVcAuaXQN), was developed. It is expected that these databases/repositories will be used as sources of information beyond the lifetime of the Action. The databases contain material from both pre-CYANOCOST publications and papers arising from the CYANOCOST Action. Based on the CYANOCOST experience, it is recommended that the following matters receive attention during the lifetime of any action or project establishing public databases: i) intellectual property rights and terms of use; ii) accessibility of information and design of the database; iii) mechanisms to ensure correctness of data; iv) continued updating of the database; and v) maintenance of the database.

To address the needs of various professional groups, including water managers, the drinking water industry, the environmental and public health sectors, and academia, CYANOCOST outcomes were communicated in the form of the three handbooks mentioned in this paper and two special issues in Aquatic Ecology and Advances in Oceanography and Limnology, i.e. the present themed issue). The handbooks and special issues have been intended to serve as coherent and up-to-date compilations of theoretical and practical knowledge relating to toxic cyanobacteria and the problems they cause. As today the scientific knowledge is scattered over a multitude of scientific individual papers, the value of single-source collections of information is probably appreciated by end-users. Furthermore, a Decision Support Tool based on the outcomes of the EU-FP6 project PEPCY was translated from German into English and has been made available on-line (https://toxische-cyanobakterien.de/en/). In order to promote networking between various professionals, the Action's Management Committee meetings have had attendees from the local water and public health authorities, water companies, and the academic community. Besides ordinary Management Committee members, representatives from different institutions in e.g. Greece, Bulgaria, Hungary, Spain, the Netherlands, etc., participated in the meetings. Representatives from other key Europe-wide projects such as the NETLAKE COST Action or the SOLUTIONS EU project attended some of the meetings, too.

As a reaction to the water crisis in Užice, Serbia, an international conference 'Water challenges of the future' was organized in Belgrade on 24 ${ }^{\text {th }}$ March 2014. This scientific and educational meeting was organized by the Faculty of Sciences of the University of Novi Sad. Eminent experts presented information on cyanobacterial blooms and production of toxic metabolites with the aim of raising preparedness, knowledge and engagement among authorities and citizens. The objective was education of target groups 
including the authorities and citizens of Užice, representatives from water-supply facilities, as well as users of recreational waters, and the provision of information on cyanotoxin problems to the institutes of public health, medical and veterinary practitioners, governmental and regional bodies, students of ecology and the general public. Furthermore, the merits of introducing guidelines and/or legislation regarding cyanotoxins in Serbia (for drinking water, recreational usage and edible fish) were discussed at the meeting with an emphasis on their introduction into national legislation on hazardous substances. The conference provided an example of how an international network can give support to local academics, authorities and other stakeholders in combatting an environmental problem.

Early-stage researchers (ESRs) and other younger professionals were seen as an important group of stakeholders. To increase awareness of cyanobacterial blooms and cyanotoxin problems among young scientists and to promote network-building, summer schools were organized. These included the Advanced Course on Cyanobacteria and Cyanotoxins, Madrid, June-July 2015, and the $12^{\text {th }}$ Summer Course on Environmental Toxicology, Brno, June 2015. Both summer schools had wide participation from many countries. Thematic expert workshops were also organized within the Action, including the training school on the use of hydrogen peroxide against cyanobacterial blooms (Amsterdam, September 2014) and the analytical workshop on BMAA (Wageningen, May 2015). Furthermore, a total of 37 STSMs were financed to promote mobility between different laboratories in countries and these exchange periods were especially targeted to ESRs.

The CYANOCOST webpage (http://www.cyanocost.c om) served as a major forum with information about the Action, the subject matter, and as a main communication medium for end-users and others interested in the recognition and risk management of cyanobacterial blooms, cyanotoxins and their impacts. This webpage has received over 30,000 visitors that have visited over 116,000 webpages in 18 months, and the visitors have posted questions, news, announcements, discussions etc. Social networks have also been used for dissemination of the CYANOCOST Action. In particular, the Twitter account (@Cyanocost)was quite successful with over 500 followers and over 2500 'tweets' from June 2013. A CYANOCOST Facebook page has also had over 350 'likes' (followers) and some posts reached to over 1000 followers.

Taken together, the dissemination efforts of the CYANOCOST Action have allowed an ample distribution of the information regarding cyanobacteria and cyanotoxins not only in COST member countries but also in other countries dealing with cyanobacterial problems such as the United States, Australia, etc.

\section{GAPS IN KNOWLEDGE AND ACTIONS NECESSARY TO STRENGTHEN MANAGEMENT CAPABILITIES}

The problem of toxic cyanobacterial blooms is primarily linked to non-sustainable consumption by the stillgrowing human population, which brings enormous pressures on global hydrological regimes, nutrient loads and on the global climate. A truly holistic approach will need to be taken at all levels to apply strategies leading to real solutions (Paerl et al., 2016) and to develop particular managerial approaches and risk mitigation measures (Bullerjahn et al., 2016; Ibelings et al., 2016). This section aims to summarize some of the open issues and knowledge gaps which require attention in order to strengthen capabilities for the management of toxic blooms in the future.

\section{Horizontal and cross-cutting issues}

With the widening of research on cyanobacteria and their toxins, and the essential involvement of different disciplines, an increasing need is emerging for a proper harmonization and definition of terminology. Terms including 'harmful blue-green algae', 'toxic' or 'toxigenic' cyanobacteria, 'cyanobacteria-1' and/or 'algal harmful blooms', and acronyms such as 'cyanoHABs' and 'CHABs' are being used in different parts of the world, in different contexts (e.g., marine $v s$ freshwater) and both within- and between different communities (e.g., scientists $v s$ stakeholders). For example, the validity of the terms 'toxic' and 'non-toxic' as applied to cyanobacteria, depends not only on the presence of cyanotoxins but also on their concentrations and/or the target organisms considered (Codd and Metcalf, 2014). Another emerging problem of terminology relates to current changes in the nomenclature and classification of cyanobacteria (Sciuto and Moro, 2015; Komárek, 2016). Current systematics and nomenclature are undergoing rapid changes that can be appreciated only by specialized scientists. However, practitioners and water managers tend to benefit rather from simplification based on mutual agreements among scientists and stakeholders. This approach helps to assure the effective exploitation of different information resources and to streamline the development of management options and policies.

The accessibility, reliability, use, and quality of the information are another complex problem related to the risk management of cyanobacteria. For example, regarding spatial information, recent meta-analysis (Merel et al., 2013a) identified a disproportionality between well-covered regions including the USA, Canada, Europe and Australia, versus other (highly vulnerable) areas including much of South America, Asia or Africa (Codd et al., 2005, Merel et al., 2013a). However, a recent survey has col- 
lated more information on activities in Africa (Ndlela et al., 2016). Further surveys in these continents are needed for truly global mapping of toxic cyanobacteria risks. Even existing information may not be fully accessible (Merel et al., 2013b). For example, blooms may eventually be monitored and cyanotoxin analyses performed, but the information may be only locally available and not reported to any recognized national or international database(s). Thus, the occurrence and potential risks of toxic blooms can be considerably underestimated, and future efforts should aim to implement 'open environmental data' principles (e.g., via the GEOSS system; https://www.earthobservations.org), and to strengthen the role of the public (i.e., via 'citizen science') in the field of toxic cyanobacterial blooms. On the contrary, there is a major lag between the speed of newly generated data on cyanobacteria (related to biotechnological advances, next generation sequencing or other 'omics'; Pearson et al., 2016), the actual 'quality' of such data (ageing), and very slow progress in the development of bioinformatics selflearning tools that would make use of these 'big data'. Finally, the current 'publish or perish' culture in the science research community also negatively affects the field of toxic cyanobacteria. Both science and the practical implementation of research results for risk management purposes would greatly benefit from improvements that could be achieved by applying more thorough and critical peerreview during the publication of research on toxic cyanobacteria.

\section{Surveys}

Surveys of cyanobacterial hazards often combine several methods including: i) taxonomy - microscopy determinations of phytoplankton; and/or ii) analyses of cyanotoxins; and/or iii) molecular biology investigations; and/or iv) observations of poisonings or other direct field effects.

The information obtained from field surveys may be used not only for immediate managerial actions but is important also for development of models and bloom dynamics predictions, which still remain a major challenge (Humbert and Fastner, 2017). Because of the variability both between and within individual waterbodies, effective predictions are currently possible only a few days in advance, and useful monitoring schemes for risk management require adaptation to local conditions, case-by-case definitions of locations or sampling and analytical details.

However, as demonstrated for example by the EMLS initiative, jointly organized by COST Actions CYANOCOST and NETLAKE, improvements in future monitoring are possible by successful combinations of harmonized methods along with continuous and real-time sampling and standardized analysis methods (Humbert and Törökné, 2017). Recently, numerous multiparameter tools have been developed and integrated into au- tonomous buoys or drones that may increase our future understanding of detailed spatial and temporal cyanobacterial bloom dynamics. Future improvements in bloom monitoring should also consider integration of aerial or space-observations (Hunter et al., 2017) and investigation of less explored factors recently suggested as drivers of toxic blooms (Carvalho et al., 2011).

Future surveys of toxigenic cyanobacteria in Europe should assess not only traditional cyanotoxins-producers but investigate also alien or invasive species as discussed in previous sections. In particular, distribution and potential toxigenicity of C. bergii, C. ovalisporum or S. aphanizomenoides should not be overlooked. Future surveys should also cover picocyanobacteria that often remain overlooked due to their very small size but they have been suggested as potential cyanotoxin-producers by numerous studies (Jasser et al., 2017). Also benthic cyanobacteria that have previously been associated with animal poisonings still remain to be fully explored (Quiblier et al., 2013), including investigations of newly observed couplings in ecology of benthic and pelagic communities (Zhang et al., 2015).

Considering the assessment of individual toxins, modern analytical equipment can easily comply with the most demanding monitoring needs, and robust multitarget methods for simultaneous quantification of multiple compounds are being developed for future implementation. As well, non-target approaches could provide more insights into profiling of cyanotoxins and other metabolites in the future. However, there is a strong need to develop regulatory guidelines for cyanotoxins which would give a higher priority to their monitoring and assessment. Another important issue for the future is the current lack of reference materials that are urgently needed for validation and improvements of standardized surveys. As also discussed in previous sections, there are disproportionalities in our knowledge of MCs versus other cyanotoxins. In particular, the occurrence of STX across Europe is poorly understood. Future surveys should provide insights into STX occurrence and risks specifically focusing e.g. on the association of STX with Cylindrospermopsis sp., which has been shown elsewhere but not investigated in Europe. With respect to CYN, the main gaps include our understanding of its role in aquatic ecosystems, and studies on factors affecting CYN biosynthesis and biodegradation are needed. Also the risks of the neurotoxic amino acid BMAA and its relevance for cyanobacterial blooms will require thorough attention and open discussion among scientists.

Despite the strengths of molecular biology tools, they are still mainly confined to the field of research, and several issues need to be addressed before they can be widely applied to environmental monitoring. It is accepted that these tools can be developed to provide high-throughput methods that can be used for early-warning purposes dur- 
ing environmental surveillance. However, due to their high sensitivity, genetic methods in general and PCR assays in particular are prone to errors, i.e. the production of false positive results. For example, in laboratories working routinely on the detection of pathogens by genetic methods, a full catalogue of quality assurance and quality control criteria needs to be met in order to guarantee reliable results. For cyanotoxin synthesis gene detection, in particular, this quality assurance catalogue still needs to be developed; hopefully based on the experience collectively presented in the new handbook on molecular tools (Kurmayer et al., 2017). Molecular tools can also be expected to make a major contribution to the understanding of the patchy occurrence of the genes for cyanotoxin biosynthesis and of the production of the toxins themselves among cyanobacteria at different levels of taxonomic resolution, e.g. within and between families, genera and species (Kurmayer et al., 2015). This variability can be observed for isolated strains and also with environmental samples on a global scale. For example, the biogeography of cyanotoxin biosynthesis might be resolved at a geographically higher resolution, using PCR-based techniques with the aim to map toxigenic genotype occurrence. Putting toxigenic genotype distribution on a map could be further combined with phylogenetic analysis to reveal the phylogeographic dependence on cyanotoxin synthesis in nature.

\section{Effects}

With respect to effects and impacts, new evidence has been collected throughout the CYANOCOST Action on a range of newly-recognised types of health hazards which cyanobacteria may present. These include for example the production of endocrine- or pro-inflammatory-modulators (Sychrova et al., 2012; Adamovsky et al., 2015), and of retinoic acid receptors which cause malformations during fish embryogenesis (Kaya and Sano, 2017). Several cyanobacterial exposure routes e.g. aerial exposure via inhalation, though long-recognised (Codd et al., 1999) require further epidemiological research. In addition, cyanobacterial mats have been discussed as the growth matrix for pathogenic microorganisms (e.g., Legionella sp., Vibrio cholerae or Clostridium sp.; Manganelli et al., 2012). Future research should critically evaluate the relevance and relative importance of microbial pathogens and further hazards including metals and pesticides to those posed by cyanobacteria. The true incidence of cyanotoxinrelated acute poisonings can hardly be fully quantified but the case reports recently summarized clearly confirm that cyanobacterial blooms present ongoing health risks to both animals and humans (Wood, 2016). In addition to traditionally studied liver and neurological symptoms following acute intoxications, new studies are needed to investigate hazards and modes of action (MoA) in other tissues or systems (immune-, intestine-, respiratory- etc.). In contrast to the relatively broad knowledge on the acute effects of cyanotoxins, the chronic exposures and related toxic risks and adverse health outcomes remain to be studied in the future (Ibelings et al., 2014).

\section{Preventative and control measures}

Despite the significant progress in our understanding of bloom development and progress in their reduction or prevention, including by in-lake technologies, future improvements are still needed. As pointed out here and summarized elsewhere (Ibelings et al., 2016), future lake management would benefit from innovative and clear recommendations on the selection of available methods, their optimization, assessment of efficacy, evaluation of their sustainability and the estimation of potential side effects. Furthermore, assessment of the overall cost-effectiveness of individual approaches should be done in the future including evaluation of investments, economic depreciation over time as well as all necessary running and maintenance costs.

With regard to the removal of cyanotoxins from waters, current technologies can allow efficient transformations of investigated individual cyanotoxins by at least one known process. However, no universal treatment has been proven to simultaneously and completely remove all cyanotoxins in mixtures, and combinations of different methods (multibarrier concept) should be implemented in advanced treatment plants (Merel et al., 2013b). Additional measures, such as cyanotoxin removal by home filters, should also be considered under specific situations. Improvements are still needed regarding water treatment under variable situations of changing $\mathrm{pH}$ or dissolved organic material also with the help of continuous monitoring tools of cyanobacterial breakthroughs (Zamyadi et al., 2014). Scale-up of promising AOPs will be needed to evaluate the cost-effectiveness and sustainability of these methods (He et al., 2012; Fotiou et al., 2016). Finally, the current lack of harmonized international and national regulatory guidelines for cyanotoxins in drinking waters is among the main obstacles for effective risk management in the future, as demonstrated e.g. in the Užice case recently (Svirčev et al., 2017b). The development of appropriate guidelines and their implementation in most-affected European regions is urgently needed.

\section{CONCLUSIONS}

As shown by this review, scientific knowledge on toxic cyanobacteria and cyanotoxins has advanced rapidly during recent years. Progress has been achieved in e.g. phycological and ecological studies, techniques for cyanotoxin analysis, molecular biology related to toxin biosynthesis, biochemical and medical studies related to cyanotoxin ac- 
tions, as well as various management and control aspects. However, the recent cyanotoxin poisonings in Europe and elsewhere illustrate clearly that water-users are still experiencing serious cyanobacterial hazards. Expertise from various professional groups and collaboration between the stakeholders are necessary in order to help to protect the safety of water consumers and users. Answers to some open key questions identified in this review are still pending and will necessitate further research efforts.

\section{ACKNOWLEDGMENTS}

The authors would like to acknowledge the European Cooperation in Science and Technology, COST Action ES 1105 'CYANOCOST - Cyanobacterial blooms and toxins in water resources: Occurrence, impacts and management' for adding value to this paper through networking and knowledge sharing with European experts and researchers in the field.

\section{REFERENCES}

Akcaalan R, Köker L, Oğuz A, Spoof L, Meriluoto J, Albay M, 2014. First report of cylindrospermopsin production by two cyanobacteria (Dolichospermum mendotae and Chrysosporum ovalisporum) in Lake Iznik, Turkey. Toxins 6:3173-3186.

Akcaalan R, Mazur-Marzec H, Zalewska A, Albay M, 2009. Phenotypic and toxicological characterization of toxic Nodularia spumigena from a freshwater lake in Turkey. Harmful Algae 8:273-278.

Adamovsky O, Moosova Z, Pekarova M, Basu A, Babica P, Sindlerova LS, Kubala L, Blaha L 2015. Immunomodulatory potency of microcystin, an important water-polluting cyanobacterial toxin. Environ. Sci. Technol. 49:12457-12464.

Agency for Environmental Protection (Agencija za zaštitu životne sredine) 2013. Accessed on: 21 January 2016. Available from: h t t p ://www.sepa.gov.rs/index.php? menu $=504000000 \& \mathrm{id}=20013$ \&akcija $=$ showArhiva

Antenucci JP, Ghadouani A, Burford MA, Romero JR, 2005. The long-term effect of artificial destratification on phytoplankton species composition in a subtropical reservoir. Freshwater Biol. 50:1081-1093.

Antoniou MG, Pelaez MA, Song W, O’Shea K, Ho L, Newcombe G, Teixeira MR, de La Cruz AA, Triantis TM, Kaloudis T, Hiskia A, Balasubramanian R, Pavagadhi S, Han C, Sharma V, Dixon M, He X, Dionysiou DD, 2014. Practices that prevent the formation of cyanobacterial blooms in water resources and remove cyanotoxins during physical treatment of drinking water, p. 173-195. In: S. Ahuja (ed.), Comprehensive water quality and purification. Elsevier.

B-Béres V, Gábor V, Dobronoki D, Gonda S, Nagy SA, Bácsi I, 2015. Effects of cylindrospermopsin producing cyanobacterium and its crude extracts on a benthic green alga - competition or allelopathy? Mar. Drugs 13:6703-6722.

Bakker ES, Hilt S, 2016. Impact of water level fluctuations on cyanobacterial blooms: options for management. Aquat. Ecol. 50:485-498.
Ballot A, Fastner J, Lentz M, Wiedner C. 2010. First report of anatoxin-a-producing cyanobacterium Aphanizomenon issatschenkoi in northeastern Germany. Toxicon 56:964-71.

Bernard C, Ballot A, Thomazeau S, Maloufi S, Furey A, Mankiewicz-Boczek J, Pawlik-Skowronska B, Capelli C, Salmaso N, 2017. Appendix 2. Cyanobacteria associated with the production of cyanotoxins, p. 503-527. In: J. Meriluoto, L. Spoof and G.A. Codd (eds.), Handbook on cyanobacterial monitoring and cyanotoxin analysis. Wiley.

Bláhová L, Oravec M, Maršálek B, Šejnohová L, Šimek Z, Bláha L, 2009. The first occurrence of the cyanobacterial alkaloid toxin cylindrospermopsin in the Czech Republic as determined by immunochemical and LC/MS methods. Toxicon 53:519-524.

Bohunická M, Mareš J, Hrouzek P, Urajová P, Lukeš M, Šmarda J, Komárek J, Gaysina LA, Sturnecký O, 2015. A combined morphological, ultrastructural, molecular, and biochemical study of the peculiar family Gomontiellaceae (Oscillatoriales) reveals a new cylindrospermopsin-producing clade of cyanobacteria. J. Phycol. 51:1040-1054.

Bormans M, Maršálek B, Jančula D, 2016. Controlling internal phosphorus loading in lakes by physical methods to reduce cyanobacterial blooms - a review. Aquat. Ecol. 50:407-422.

Bullerjahn GS, McKay RM, Davis TW, Baker DB, Boyer BL, D'Anglada LV, Doucette GJ, Ho JC, Irwin EG, Kling EG, Kudela RM, Kurmayer R, Michalak AM, Ortiz JD, Otten TG, Paerl HW, Qin BQ, Sohngen BL, Stumpf RP, Visser PM, Wilhelm SW, 2016. Global solutions to regional problems: Collecting global expertise to address the problem of harmful cyanobacterial blooms. A Lake Erie case study. Harmful Algae 54:223-238.

Bowling LC, Baker PD, 1996. Major cyanobacterial bloom in the Barwon-Darling river, Australia, in 1991, and underlying limnological conditions. Mar. Freshw. Res. 47:643-657.

Bradley WG, Mash DC, 2009. Beyond Guam: The cyanobacteria/BMAA hypothesis of the cause of ALS and other neurodegenerative diseases. Amyotroph. Lateral Scler. 10:7-20.

Brient L, Lengronne M, Bormans M, Fastner J, 2009. First occurrence of cylindrospermopsin in freshwater in France. Environ. Toxicol. 24:415-420.

Brown NM, Mueller RS, Shepardson JW, Landry ZC, Morré JT, Maier CS, Hardy FJ, Dreher TW, 2016. Structural and functional analysis of the finished genome of the recently isolated toxic Anabaena sp. WA102. BMC Genomics 17:1-18.

Carvalho L, Miller CA, Scott EM, Codd GA, Davies PS, Tyler AN, 2011. Cyanobacterial blooms: Statistical models describing risk factors for national-scale lake assessment and lake management. Sci. Total. Environ. 409:5353-5358.

Chen Q, Christiansen G, Deng L, Kurmayer R, 2016. Emergence of nontoxic mutants as revealed by single filament analysis in bloom-forming cyanobacteria of the genus Planktothrix. BMC Microbiol. 16:1-12.

Christiansen G, Fastner J, Erhard M, Börner T, Dittmann E, 2003. Microcystin biosynthesis in Planktothrix: genes, evolution, and manipulation. J. Bacteriol. 185:564-572.

Cirés S, Ballot A, 2016. A review of the phylogeny, ecology and toxin production of bloom-forming Aphanizomenon spp. and related species within the Nostocales (cyanobacteria). Harmful Algae 54:21-43.

Cirés S, Wörmer L, Ballot A, Agha R, Wiedner C, Velázquez D, 
Casero MC, Queseda A, 2014. Phylogeography of cylindrospermopsin and paralytic shellfish toxin-producing Nostocales cyanobacteria from Mediterranean Europe (Spain). Appl. Environ. Microbiol. 80:1359-70.

Codd GA, Azevedo SMFO, Bagchi SN, Burch MD, Carmichael WW, Harding WR, Kaya K, Utkilen HC, 2005. CYANONET - A Global Network for Cyanobacterial bloom and Toxin Risk Management. Initial Situation Assessment and Recommendations. International Hydrobiological Programme. Technical Documents in Hydrology No. 76. UNESCO, Paris: 138 pp.

Codd GA, Bell SG, Kaya K, Ward CJ, Beattie KA, Metcalf JS, 1999. Cyanobacterial toxins, exposure routes and human health. Eur. J. Phycol 34:405-415.

Codd GA, Metcalf JS, 2014. Toxic and non-toxic cyanobacteria: evolving concepts. Perspect. Phycol. 1: 3-5.

Codd GA, Testai E, Funari E, Svirčev Z (2017). Cyanobacteria, cyanotoxins and human health. In: A. Hiskia, D. Dionysiou, M. Antoniou, T. Kaloudis, and T. Triantis (eds.), Water treatment for purification from cyanobacteria and cyanotoxins. Wiley (in press).

Cohen SA, 2012. Analytical techniques for the detection of $\alpha$ amino- $\beta$ - methylaminopropionic acid. Analyst 137:1991-2005.

Cox PA, Banack SA, Murch SJ, Rasmussen U, Tien G, Bidigare RR, Metcalf JS, Morrison LF, Codd GA, Bergman B, 2005. Diverse taxa of cyanobacteria produce $\beta$ - $N$-methylamino-Lalanine, a neurotoxic amino acid. P. Natl. Acad. Sci. USA 102: 5074-5078.

Devic E, Li D, Dauta A, Henriksen P, Codd GA, Marty J-L, Fournier D, 2002. Detection of anatoxin-a(s) in environmental samples of cyanobacteria using a biosensor with engineered acetylcholinesterases. Appl. Environ. Microbiol. 68:4102-4106.

Đenić D, 2014. Cyanobacterial blooms in Vrutci reservoir (Cvetanje cijanobakterija u hidroakumulaciji Vrutci). Master's thesis, University of Novi Sad, Serbia.

Đorđević NB, Simić SB, Ćirić AR, 2015. First identification of the cylindrospermopsin (CYN)-producing cyanobacterium Cylindrospermopsis raciborskii (Wołoszyńska) Seenaya \& Subba Raju in Serbia. Fresen. Environ. Bull. 24:3736-3742.

Douglas GB, Hamilton DP, Robb MS, Pan G, Spears BM, Lürling M, 2016. Guiding principles for the development and application of solid phase phosphorus- adsorbents for freshwater ecosystems. Aquat. Ecol. 50:385-406.

Drobac D, 2015. Human exposure to cyanotoxins and their health effects (Putevi izloženosti čoveka cijanotoksinima $i$ njihov uticaj na zdravlje). Doctoral dissertation. University of Novi Sad.

Duncan MW, 2012. Good mass spectrometry and its place in good science. J. Mass. Spectrom. 47:795-809.

Dziga D, Kokociński M, Maksylewicz A, Czaja-Prokop U, Barylski J, 2016. Cylindrospermopsin biodegradation abilities of Aeromonas sp. isolated from Rusałka Lake. Toxins (Basel) 8:55.

de la Cruz AA, Hiskia A, Kaloudis T, Chernoff N, Hill D, Antoniou MG, He X, Loftin K, O'Shea K, Zhao C, Pelaez M, Han C, Lynch TJ, Dionysiou DD, 2013. A review on cylindrospermopsin: the global occurrence, detection, toxicity and degradation of a potent cyanotoxin. Environ. Sci. Process. Impacts 15:1979-2003.
Edwards C, Beattie KA, Scrimgeour CM, Codd GA, 1992. Identification of anatoxin-a in benthic cyanobacteria (blue-green algae) and in associated dog poisonings at Loch Insh, Scotland. Toxicon 30:1665-1175.

Elersek T, Bláha L, Mazur $\square$ Marzec H, Schmidt W, Carmeli S, 2017. Other cyanobacterial bioactive substances, p. 179-195. In: J. Meriluoto, L. Spoof and G.A. Codd (eds.), Handbook on cyanobacterial monitoring and cyanotoxin analysis. Wiley.

Faassen EJ, 2014. Presence of the neurotoxin BMAA in aquatic ecosystems: What do we really know? Toxins 6:1109-1138.

Faassen EJ, Antoniou MG, Beekman-Lukassen W, Blahova L, Chernova E, Christophoridis C, Combes A, Edwards C, Fastner J, Harmsen J, Hiskia A, Ilag LL, Kaloudis T, Lopicic S, Lürling M, Mazur-Marzec H, Meriluoto J, Porojan C, Viner-Mozzini Y, Zguna N, 2016. A collaborative evaluation of LC-MS/MS based methods for BMAA analysis: Soluble bound BMAA found to be an important fraction. Mar. Drugs $14: 45$.

Faassen EJ, Gillissen F, Lürling M, 2012a. A comparative study on three analytical methods for the determination of the neurotoxin BMAA in cyanobacteria. PLoS One 7:e36667.

Faassen EJ, Harkema L, Begeman L, Lürling M, 2012b. First report of (homo)anatoxin-a and dog neurotoxicosis after ingestion of benthic cyanobacteria in The Netherlands. Toxicon 60:378-384.

Fastner J, Abella S, Litt A, Morabito G, Vörös L, Pálffy K, Straile D, Kümerlin R, Matthews D, Phillips MG, Chorus I, 2016. Combating cyanobacterial proliferation by avoiding or treating inflows with high P load - experiences from eight case studies. Aquat. Ecol. 50:367-384.

Fastner J, Heinze R, Humpage AR, Mischke U, Eaglesham GK, Chorus I, 2003. Cylindrospermopsin occurrence in two German lakes and preliminary assessment of the toxicity and toxin production of Cylindrospermopsis raciborskii cyanobacteria isolates. Toxicon 42:313-321.

Fischbach MA, Walsh CT, 2006. Assembly-line enzymology for polyketide and nonribosomal peptide antibiotics: Logic, machinery, and mechanisms. Chem. Rev. 106:3468-3496.

Fotiou T, Triantis TM, Kaloudis T, O'Shea KE, Dionysiou DD, Hiskia A, 2016. Assessment of the roles of reactive oxygen species in the UV and visible light photocatalytic degradation of cyanotoxins and water taste and odor compounds using C-TiO2. Water Res. 90: 52-61.

Furey A, Crowley J, Shuilleabhain AN, Skulberg OM, James KJ. 2003. The first identification of the rare cyanobacterial toxin, homoanatoxin-a, in Ireland. Toxicon 41:297-303.

Gkelis S, Zaoutsos N, 2014. Cyanotoxin occurrence and potentially toxin producing cyanobacteria in freshwaters of Greece: a multi-disciplinary approach. Toxicon 78:1-9.

Gugger M, Lenoir S, Berger C, Ledreux A, Druart J-C, Humbert J-F, Guette C, Bernard C, 2005. First report in a river in France of the benthic cyanobacterium Phormidium favosum producing anatoxin-a associated with dog neurotoxicosis. Toxicon 45:919-28.

Guzmán-Guillén R, Prieto AI, Moreno IM, Vasconcelos VM, Moyano R, Blanco A, Cameán AM, 2015. Cyanobacterium producing cylindrospermopsin causes histopathological changes at environmentally relevant concentrations in subchronically exposed tilapia (Oreochromis niloticus). Environ. Toxicol. 30:261-277. 
Hamilton DP, Salmoso N, Pearl HW, 2016. Catchment control strategies to mitigate harmful cyanobacterial blooms: nitrogen and phosphorus controls. Aquat. Ecol. 50:351-366.

He X, Pelaez M, Williams C, Westrick JA, O'Shea KE, Hiskia A, Triantis T, Kaloudis T, de la Cruz AA, Dionysiou DD, 2012. Efficient removal of microcystin-LR by UV-C/H2O2 in synthetic and natural water samples. Water Res. 46:1501-1510.

Henriksen P, Carmichael WW, An J, Moestrup Ø, 1997. Detection of an anatoxin-a(s)-like anticholinesterase in natural blooms and cultures of cyanobacteria/blue-green algae from Danish lakes and in the stomach contents of poisoned birds. Toxicon 35: 901-913.

Hicks LM, Moffitt MC, Beer LL, Moore BS, Kelleher NL, 2006. Structural characterization of in vitro and in vivo intermediates on the loading module of microcystin synthetase. ACS Chem. Biol. 1:93-102.

Hiskia A, Dionysiou D, Antoniou M, Kaloudis T, Triantis T (eds.), 2017. Water Treatment for Purification from Cyanobacteria and Cyanotoxins, Wiley (in press).

Ho L, Tanis-Plant P, Kayal N, Slyman N, Newcombe G, 2009. Optimising water treatment practices for the removal of $\mathrm{An}$ abaena circinalis and its associated metabolites, geosmin and saxitoxins. J. Water Health 7:544-56.

Humbert J-F, Fastner J, 2017. Ecology of cyanobacteria, p. 1118. In: J. Meriluoto, L. Spoof, and G.A. Codd (eds.), Handbook on Cyanobacterial Monitoring and Cyanotoxin Analysis, Wiley.

Humbert J-F, Törökné A., 2017. New tools for the monitoring of cyanobacteria in freshwater ecosystems, p. 84-88. In: J. Meriluoto, L. Spoof, and G.A. Codd (eds.), Handbook on Cyanobacterial Monitoring and Cyanotoxin Analysis, Wiley.

Hunter PD, Matthews MW, Kutser T, Tyler AN, 2017. Remote sensing of cyanobacterial blooms in inland, coastal, and ocean Waters, p. 89-99. In: J. Meriluoto, L. Spoof, and G.A. Codd (eds.), Handbook on Cyanobacterial Monitoring and Cyanotoxin Analysis, Wiley.

Ibelings BW, Admiraal W, Bijkerk R, Ietswaart T, Prins H, 1998. Monitoring of algae in Dutch rivers: does it meet its goals? J. Appl. Phycol. 2:171-181.

Ibelings BW, Backer LC, Kardinaal WEA, Chorus I, 2014. Current approaches to cyanotoxin risk assessment and risk management around the globe. Harmful Algae 40:63-74.

Ibelings BW, Bormans M, Fastner J, Visser PM, 2016. CYANOCOST special issue on cyanobacterial blooms - a critical review of the management options for their prevention, control and mitigation. Aquat. Ecol. 50:595-605.

Institute of Public Health Serbia "Dr Milan Jovanović Batut" 2014. Report on the request for access to information of public importance No.8301/1, Belgrade. http://uimenaroda.rs/predmeti/li\%C4\%8Dni-stav/190-u\%C5\%BEice-vodosnabdevanje-slika-srbije.html (accessed 21 January 2016).

Jasser I, Callieri C, 2017. Picocyanobacteria: the smallest cellsize cyanobacteria, p. 19-27. In: J. Meriluoto, L. Spoof, and G.A. Codd (eds.), Handbook on Cyanobacterial Monitoring and Cyanotoxin Analysis, Wiley.

Jiang YG, Xiao P, Yu GL, Sano T, Pan QQ, Li RH, 2012. Molecular basis and phylogenetic implications of deoxycylindrospermopsin biosynthesis in the cyanobacterium Raphidiopsis curvata. Appl. Environ. Microbiol. 78:2256-2263.

Jiang L, Eriksson J, Lage S, Jonasson S, Shams S, Mehine M,
Ilag LL, Rasmussen U, 2014a. Diatoms: a novel source for the neurotoxin BMAA in aquatic environments. PLoS ONE 9(1):e84578.

Jiang L, Kiselova N, Rosén J, Ilag LL, 2014b. Quantification of neurotoxin BMAA ( $\beta$-N-methylamino-L-alanine) in seafood from Swedish markets. Sci. Rep. 4:6931.

Jungblut A, Neilan B, 2006. Molecular identification and evolution of the cyclic peptide hepatotoxins, microcystin and nodularin, synthetase genes in three orders of cyanobacteria. Arch. Microbiol. 185:107-114.

Kaštovskỳ J, Hauer T, Mareš J, Krautová M, Bešta T, Komárek J, Desortová B, Heteša J, Hindáková A, Houk V, Janeček E, Kopp R, Marvan P, Pumann P, Skácelova O, Zapomělová E, 2010. A review of the alien and expansive species of freshwater cyanobacteria and algae in the Czech Republic. Biol. Invasions 12:3599-3625.

Kaya K, Sano T, 2017. Cyanobacterial retinoids, p. 173-178. In: J. Meriluoto, L. Spoof, and G.A. Codd (eds.), Handbook on Cyanobacterial Monitoring and Cyanotoxin Analysis, Wiley.

Kellmann R, Mihali TK, Jeon YJ, Pickford R, Pomati F, Neilan BA, 2008. Biosynthetic intermediate analysis and functional homology reveal a saxitoxin gene cluster in cyanobacteria. Appl. Environ. Microbiol. 74:4044-4053.

Kiss T, Vehovszky A, Hiripi L, Kovacs A, Voros L, 2002. Membrane effect of toxins isolated from a Cyanobacterium, Cylindropermopsis raciborskii, on identified molluscan neurons. Comp. Biochem. Physiol. C Toxicol. Pharmacol. 131C:167-176.

Kobos J, Błaszczyk A, Hohlfeld N, Toruńska-Sitarz A, Krakowiak A, Hebel A, Sutryk K, Grabowska M, Toporowska M, Kokociński M, Messyasz B, Rybak A, Napiórkowska-Krzebietke A, Nawrocka L, Pełechata A, Budzyńska A, Zagajewski P, Mazur-Marzec H, 2013. Cyanobacteria and cyanotoxins in Polish freshwater bodies. Oceanol. Hydrobiol. Stud. 42:358-378.

Kokociński M, Dziga D, Spoof L, Stefaniak K, Jurczak T, Mankiewicz-Boczek J, Meriluoto J, 2009. First report of the cyanobacterial toxin cylindrospermopsin in the shallow, eutrophic lakes of western Poland. Chemosphere. 74:669-675.

Kokociński M, Akçaalan R, Salmaso N, Stoyneva-Gärtner MP, Sukenik A, 2017. Expansion of alien and invasive cyanobacteria, p. 28-39. In: J. Meriluoto, L. Spoof, and G.A. Codd (eds.), Handbook on Cyanobacterial Monitoring and Cyanotoxin Analysis, Wiley.

Kokociński M, Mankiewicz-Boczek J, Jurczak T, Spoof L, Meriluoto J, Rejmonczyk E, Hautala H, Vehniäinen M, Pawełczyk J, Soininen J, 2013. Aphanizomenon gracile (Nostocales), a cylindrospermopsin-producing cyanobacterium in Polish lakes. Environ. Sci. Pollut. Res. Int. 20:5243-5264.

Komárek J, 2016. A polyphasic approach for the taxonomy of cyanobacteria: principles and applications. Eur. J. Phycol. 51:346-353.

Koreivienė J, Kasperovičenė J, 2011. Alien cyanobacteria Anabaena bergii var. limnetica Coute et Preisig from Lithuania: Some aspects of taxonomy, ecology and distribution. Limnologica 41: 325-333.

Koskenniemi K, Lyra C, Rajaniemi-Wacklin P, Jokela J, Sivonen K, 2007. Quantitative real-time PCR detection of toxic Nodularia cyanobacteria in the Baltic Sea. Appl. Environ. Microbiol. 73:2173-2179. 
Kurmayer R, Blom JF, Deng L, Pernthaler J, 2015. Integrating phylogeny, geographic niche partitioning and secondary metabolite synthesis in bloom-forming Planktothrix. ISME J. 9:909-921.

Kurmayer R, Sivonen K, Wilmotte A, Salmaso N (eds.), 2017. Molecular Tools for the Detection and Quantification of Toxigenic Cyanobacteria. Wiley (in press).

Lage S, Burian A, Rasmussen U, Costa PR, Annadotter H, Godhe A, Rydberg S, 2015. BMAA extraction of cyanobacteria samples: which method to choose? Environ. Sci. Pollut. Res. Int. 23(1):338-350.

Ledreux A, Thomazeau S, Catherine A, Duval C, Yéprémian C, Marie A, et al. 2010. Evidence for saxitoxins production by the cyanobacterium Aphanizomenon gracile in a French recreational water body. Harmful Algae. 10:88-97.

Li R, Carmichael WW, Brittain JE, Eaglesham GK, Shaw GR, Mahakhant A, Noparatnaraporn N, Yongmanitchai W, Kaya $\mathrm{K}$, Watanabe MM, 2001. Isolation and identification of the cyano-toxin cylindrospermopsin and deoxycylindrospermopsin from a Thailand strain of Cylindrospermopsis raciborskii (Cyanobacteria). Toxicon 39:973-980

Lürling M, Faassen EJ, 2013. Dog poisoning associated with a Microcystis aeruginosa bloom in the Netherlands. Toxins 5:556-567.

Lürling M, Waajen G, de Senerpont Domis LN, 2016. Evaluation of several end-of-pipe measures proposed to control cyanobacteria. Aquat. Ecol. 50:499-520.

Manganelli M, Scardala S, Stefanelli M, Palazzo F, Funari E, Vichi S, Buratti FM, Testai E, 2012. Emerging health issues of cyanobacterial blooms. Ann. Ist. Super. Sanita 48:415-428.

Manti G, Mattei D, Messineo V, Melchiorre S, Bogialli S, Sechi N, Casiddu P, Luglie' A, Di Brizio M, Bruno M, 2005. First report of Cylindrospermopsis raciborskii in Italy. Harmful Algae News 28: 8-9.

Mantzouki E, Visser PM, Bormans M, Ibelings BW, 2016. Understanding the key ecological traits of cyanobacteria as a basis for their management and control in changing lakes. Aquat. Ecol. 50:333-350.

Matthijs HCP, Jančula D, Visser PM, Maršálek B, 2016. Existing and emerging cyanocidal compounds, new perspectives for cyanobacterial bloom mitigation. Aquat. Ecol. 50:443-460.

Mazmouz R, Chapuis-Hugon F, Pichon V, Méjean A, Ploux O, 2011. The last step of the biosynthesis of the cyanotoxins cylindrospermopsin and 7-epi-cylindrospermopsin is catalysed by CyrI, a 2-oxoglutarate-dependent iron oxygenase. ChemBioChem 12:858-862.

Mazur-Marzec H, Kaczkowska MJ, Blaszczyk A, Akcaalan R, Spoof L, Meriluoto J, 2013. Diversity of peptides produced by Nodularia spumigena from various geographical regions. Mar. Drugs 11:1-19.

Méjean A, Mann S, Maldiney T, Vassiliadis G, Lequin O, Ploux O, 2009. Evidence that biosynthesis of the neurotoxic alkaloids anatoxin-a and homoanatoxin-a in the cyanobacterium Oscillatoria PCC 6506 occurs on a modular polyketide synthase initiated by L-Proline. J. Am. Chem. Soc. 131:7512-7513.

Méjean A., Paci G, Gautier V, Ploux O, 2014. Biosynthesis of anatoxin-a and analogues (anatoxins) in cyanobacteria. Toxicon 91:15-22.

Merel S, Villarin MC, Chung K., Snyder S, 2013a Spatial and thematic distribution of research on cyanotoxins. Toxicon 76:118-131.

Merel S, Walker D, Chicana R, Snyder S, Baures E, Thomas O, 2013b State of knowledge and concerns on cyanobacterial blooms and cyanotoxins. Environ. Int.. 59:303-327.

Meriluoto J, Spoof L, Codd GA (eds.), 2017. Handbook of Cyanobacterial Monitoring and Cyanotoxin Analysis. Wiley.

Messineo V, Bogialli S, Melchiorre S, Sechi N, Lugliè A, Casiddu P, Mariani MA, Padedda BM, Di Corcia A, Mazza R, Carloni E, Bruno M, 2009. Cyanobacterial toxins in Italian freshwaters. Limnologica 39:95-106.

Metcalf JS, Richer R, Cox PA, Codd GA, 2012. Cyanotoxins in desert environments may present a risk to human health. Sci. Total Environ. 421-422:118-123.

Mihali TK, Kellmann R, Muenchhoff J, Barrow KD, Neilan BA, 2008. Characterization of the gene cluster responsible for cylindrospermopsin biosynthesis. Appl. Environ. Microbiol. 74:716-722.

Mitrovic SM, Hardwick L, Dorani F, 2011. Use of flow management to mitigate cyanobacterial blooms in the Lower Darling River, Australia. J. Plankton Res. 2:229-241.

Moffitt MC, Neilan BA, 2004. Characterization of the nodularin synthetase gene cluster and proposed theory of the evolution of cyanobacterial hepatotoxins. Appl. Environ. Microbiol. 70:6353-6362.

Murch SJ, Cox PA, Banack SA, 2004. A mechanism for slow release of biomagnified cyanobacterial neurotoxins and neurodegenerative disease in Guam. Proc. Natl. Acad. Sci. U.S.A. 101: 12228-12231.

Murray SA, Mihali TK, Neilan BA, 2011. Extraordinary conservation, gene loss, and positive selection in the evolution of an ancient neurotoxin. Mol. Biol. Evol. 28(3):1173-1182.

Ndlela LL, Oberholster PJ, Van Wyk JH, Cheng PH, 2016. An overview of cyanobacterial bloom occurrences and research in Africa over the last decade. Harmful Algae 60:11-26

Newcombe G, 2002. Removal of Algal Toxins from Drinking Water Using Ozone and GAC. AWWA Research Foundation and American Water Works Association, Denver, CO, USA: 133 pp.

Noordhuis R, van Zuidam BG, Peeters ETHM, 2016. Further improvements in water quality of the Dutch borderlakes: two types of clear states at different nutrient levels. Aquat. Ecol. 50:521-540.

Ohtani I, Moore RE, Runnegar MTC, 1992. Cylindrospermopsin: a potent hepatotoxin from the blue-green alga Cylindrospermopsis raciborskii. J. Am. Chem. Soc. 114:7941-7942

Okello W, Ostermaier V, Portmann C, Gademann K, Kurmayer $\mathrm{R}, 2010$. Spatial isolation favours the divergence in microcystin net production by Microcystis in Ugandan freshwater lakes. Water Res. 44:2803-2814.

O'Neil JM, Davis TW, Burford MA, Gobler CJ, 2012. The rise of harmful cyanobacteria blooms: The potential roles of eutrophication and climate change. Harmful Algae 14:313334.

Onodera H, Oshima Y, Henriksen P, Yasumoto T, 1997. Confirmation of anatoxin-a(s), in the cyanobacterium Anabaena lemmermannii, as the cause of bird kills in Danish lakes. Toxicon 35: 1645-1648.

Osswald J, Rellán S, Gago-Martinez A, Vasconcelos V, 2009. Production of anatoxin-a by cyanobacterial strains isolated 
from Portuguese fresh water systems. Ecotoxicology 18:1110-1115.

Ostermaier V, Kurmayer R, 2010. Application of real-time PCR to estimate toxin production by the cyanobacterium Planktothrix sp. Appl. Environ. Microbiol. 76:3495-3502.

Paerl HW, Gardner WS, Havens KE, Joyner AR, McCarthy MJ, Newell SE, Qin BQ, Scott JT, 2016. Mitigating cyanobacterial harmful algal blooms in aquatic ecosystems impacted by climate change and anthropogenic nutrients. Harmful Algae 54:213-222.

Pearson LA, Dittmann E, Mazmouz R, Ongley SE, P. D'Agostino M, Neilan BA, 2016. The genetics, biosynthesis and regulation of toxic specialized metabolites of cyanobacteria. Harmful Algae 54:98-111.

Poniedziałek B, Rzymski P, Wiktorowicz K, 2014. Toxicity of cylindrospermopsin in human lymphocytes: proliferation, viability and cell cycle studies. Toxicol. In Vitro 5: 968-974.

Poniedziałek B, Rzymski P, Kokociński M, Karczewski J, 2015. Toxic potencies of metabolite(s) of non-cylindrospermopsin producing Cylindrospermopsis raciborskii isolated from temperate zone in human white cells. Chemosphere 120:608-614.

Quesada A, Moreno E, Carrasco D, Paniagua T, Wormer L, De Hoyos C, Sukenik A, 2006. Toxicity of Aphanizomenon ovalisporum (Cyanobacteria) in Spanish water reservoir. Eur. J. Phycol. 41:39-45.

Quiblier C, Wood S, Echenique-Subiabre I, Heath M, Villeneuve A, Humbert JF, 2013. A review of current knowledge on toxic benthic freshwater cyanobacteria - Ecology, toxin production and risk management. Water Res. 47:5464-5479.

Rantala A, Fewer DP, Hisbergues M, Rouhiainen L, Vaitomaa J, Börner T, Sivonen K, 2004. Phylogenetic evidence for the early evolution of microcystin synthesis. Proc. Natl. Acad. Sci. U.S.A. 101:568-573.

Rantala-Ylinen A, Kana S, Wang H, Rouhiainen L, Wahlsten M, Rizzi E, Berg K, Gugger M, Sivonen K, 2011. Anatoxin-a synthetase gene cluster of the cyanobacterium Anabaena sp Strain 37 and molecular methods to detect potential producers. Appl. Environ. Microbiol. 77:7271-7278.

Rapala J, Robertson A, Negri AP, Berg KA, Tuomi P, Lyra C, Erkomaa K, Lahti K, Hoppu K, Lepistö L, 2005. First report of saxitoxin in Finnish lakes and possible associated effects on human health. Environ. Toxicol. 20:331-40.

Réveillon D, Abadie E, Séchet V, Masseret E, Hess P, Amzil Z, 2015. $\beta$-N-methylamino-l-alanine (BMAA) and isomers: Distribution in different food web compartments of Thau lagoon, French Mediterranean Sea. Mar. Environ. Res. 110:8-18.

Réveillon D, Séchet V, Hess P, Amzil Z, 2016a. Production of BMAA and DAB by diatoms (Phaeodactylum tricornutum, Chaetoceros sp., Chaetoceros calcitrans and, Thalassiosira pseudonana) and bacteria isolated from a diatom culture. Harmful Algae 58:45-50.

Réveillon D, Séchet V, Hess P, Amzil Z, 2016b. Systematic detection of BMAA ( $\beta$-N-methylamino-l-alanine) and DAB (2,4-diaminobutyric acid) in mollusks collected in shellfish production areas along the French coasts. Toxicon 110:35-46.

Rodriguez E, Sordo A, Metcalf JS, Acero JL, 2007. Kinetics of the oxidation of cylindrospermopsin and anatoxin-a with chlorine, monochloramine and permanganate. Water Res. 41:2048-2056.
Rzymski P, Poniedziałek B, 2014. In search of environmental role of cylindrospermopsin: a review on global distribution and ecology of its producers. Water Res. 66:320-337.

Rosén J, Westerberg E, Schmiedt S, Hellenäs KE, 2016. BMAA detected as neither free nor protein bound amino acid in blue mussels. Toxicon 109:45-50.

Sahindokuyucu Kocasari F, Gulle I, Kocasari S, Pekkaya S, Mor F, 2015. The occurrence and levels of cyanotoxin nodularin from Nodularia spumigena in the alkaline and salty Lake Burdur, Turkey. J. Limnol. 74:530-536.

Saker ML, Neilan BA, 2001. Varied diazotrophies, morphologies, and toxicities of genetically similar isolates of Cylindrospermopsis raciborskii (Nostocales, Cyanophyceae) from northern Australia. Appl. Environ. Microbiol. 67:1839-1845.

Savela H, Spoof L, Perälä N, Preede M, Lamminmäki U, Nybom S, Häggqvist K, Meriluoto J, Vehniäinen M, 2015. Detection of cyanobacterial sxt genes and paralytic shellfish toxins in freshwater lakes and brackish waters on Åland Islands, Finland. Harmful Algae 46:1-10.

Sciuto K, Moro I, 2015. Cyanobacteria: the bright and dark sides of a charming group. Biodivers. Conserv. 24:711-738.

Shalev-Alon G, Sukenik A, Livnah O, Schwarz R, Kaplan A, 2002. A novel gene encoding amidinotransferase in the cylindrospermopsin-producing cyanobacterium Aphanizomenon ovalisporum. FEMS Microbiol. Lett. 209:87-91.

Sharma VK, Triantis TM, Antoniou MG, He X, Pelaez M, Han C, Song W, O'Shea KE, de la Cruz AA, Kaloudis T, Hiskia A, Dionysiou DD, 2012. Destruction of microcystins by conventional and advanced oxidation processes: A review. Sep. Purif. Technol. 91:3-17.

Sierosławska A, Rymuszka A, 2015. Effects of cylindrospermopsin on a common carp leucocyte cell line. J. Appl. Toxicol. 35:83-89.

Simeunović J, Svirčev Z, Karaman M, Knezević P, Melar M 2010. Cyanobacterial blooms and first observation of microcystin occurrences in freshwater ecosystems in Vojvodina region (Serbia). Fresen. Environ. Bull. 19:198-207.

Sklenar K, Westrick J, Szlag D, 2016. Managing Cyanotoxins in Drinking Water: A Technical Guidance Manual for Drinking Water Professionals. American Water Works Association and Water Research Foundation, Denver, CO, USA: 61 pp.

Spoof L, Berg KA, Rapala J, Lahti K, Lepistö L, Metcalf JS, Codd GA, Meriluoto J, 2006. First observation of cylindrospermopsin in Anabaena lapponica isolated from the boreal environment (Finland). Environ. Toxicol. 21:552-560.

Stirling DJ, Quilliam MA, 2001. First report of the cyanobacterial toxin cylindrospermopsin in New Zealand. Toxicon 39:1219-1222.

Stroom JM, Kardinaal WEA, 2016. How to combat cyanobacterial blooms: strategy toward preventive lake restoration and reactive control measures. Aquat. Ecol. 50:521-576.

Sukenik A, Quesada A, Salmaso N, 2015. Global expansion of toxic and non-toxic cyanobacteria: effect on ecosystem functioning. Biodivers. Conserv. 24:889-908.

Svirčev Z, Drobac D, Tokodi N, Lužanin Z, Munjas AM, Nikolin B, Vuleta D, Meriluoto J, 2014a. Epidemiology of cancers in Serbia and possible connection with cyanobacterial blooms. J. Env. Sci. Health C Environ. Carcinog. Ecotoxicol. Rev. 32:319-337.

Svirčev Z, Drobac D, Tokodi N, Codd GA, Meriluoto J, 2017a. 
Toxicology of microcystins with reference to cases of human intoxications and epidemiological investigations of exposures to cyanobacteria and cyanotoxins. Arch. Toxicol. 91:621-650.

Svirčev Z, Drobac D, Tokodi N, Đenić D, Simeunović J, Hiskia A, Kaloudis T, Mijović B, Šušak S, Protić M, Vidović M, Onjia A, Nybom S, Važić T, Palanački Malešević T, Dulić T, Pantelić D, Vukašinović M, Meriluoto J, 2017b. Lessons from the Užice case: how to complement analytical data, p. 298-308. In: J Meriluoto, L Spoof, and GA Codd (eds.), Handbook of Cyanobacterial Monitoring and Cyanotoxin Analysis, Wiley.

Svirčev Z, Obradović V, Codd GA, Marjanović P, Spoof L, Drobac D, Tokodi N, Petković A, Nenin T, Simeunović J, Važić T, Meriluoto M, 2016. Massive fish mortality and Cylindrospermopsis raciborskii bloom in Aleksandrovac Lake. Ecotoxicology 25:1352-1363.

Svirčev Z, Simeunović J, Subakov-Simić G, Krstić S, Pantelić D, Dulić T, 2013. Cyanobacterial blooms and their toxicity in Vojvodina lakes, Serbia. Int. J. Environ. Res. 7:745-758.

Svirčev Z, Tokodi N, Drobac D, Codd GA, 2014b. Cyanobacteria in aquatic ecosystems in Serbia: effects on water quality, human health and biodiversity. System. Biodivers. 12:261-270.

Sychrova E, Stepankova T, Novakova K, Blaha L, Giesy JP, Hilscherova H, 2012. Estrogenic activity in extracts and exudates of cyanobacteria and green algae. Environ. Int. 39:134-140.

Testai E, Scardala S, Victu S, Buratti M, Funari E, 2016. Risk to human health associated with the environmental occurrence of cyanobacterial neurotoxic alkaloids anatoxins and saxitoxins. Crit. Rev. Toxicol. 46:285-419.

Tillett D, Dittmann E, Erhard M, vonDöhren H, Börner T, Neilan BA, 2000. Structural organization of microcystin biosynthesis in Microcystis aeruginosa PCC7806: an integrated peptide-polyketide synthetase system. Chem. Biol. 7:753-764.

Triest L, Stiers I, Van Onsem S, 2016. Biomanipulation as a nature-based solution to reduce cyanobacterial blooms. Aquat. Ecol. 50:461-484.
Van Dolah ER, Paolisso M, Sellner K, Place A, 2016. Employing a socio-ecological systems approach to engage harmful algal blooms stakeholders. Aquat. Ecol. 50:577-594.

Verspagen JM, Passarge J, Jöhnk KD, Visser PM, Peperzak L, Boers P, Laanbroek HJ, Huisman J, 2006. Water management strategies against toxic Microcystis blooms in the Dutch delta. Ecol. Appl. 16:313-327.

Visser PM, Ibelings BW, Bormans M, Huisman J, 2016a. Artificial mixing to control cyanobacterial blooms: a review. Aquat. Ecol. 50:423-442.

Visser PM, Ibelings BW, Fastner J, Bormans M (eds.), 2016 b. Special Issue 'Cyanobacterial blooms. Ecology, prevention, mitigation and control.' Aquat Ecol. 50:327-605.

Webster IT, Sherman BS, Bormans, M, Jones G, 2000. Management strategies for cyanobacterial blooms in an impounded lowland river. Regul. Rivers Res. Manag. 16:513-525.

Wimmer KM, Strangman WK, Wright JLC, 2014. 7-Deoxydesulfo-cylindrospermopsin and 7-deoxy-desulfo-12-acetylcylindrospermopsin: two new cylindrospermopsin analogs isolated from a Thai strain of Cylindrospermopsis raciborskii. Harmful Algae 37: 203-206.

Wood R, 2016. Acute animal and human poisonings from cyanotoxin exposure - A review of the literature. Environ. Int. 91:276-282.

Zamyadi A, Dorner S, Ndong M, Ellis D, Bolduc A, Bastien C, Prevost M, 2014. Application of in vivo measurements for the management of cyanobacteria breakthrough into drinking water treatment plants. Environ. Sci. Process. Impacts 16:313-323.

Zervou S-K, Christophoridis C, Kaloudis T, Triantis TM, Hiskia A, 2017. New SPE-LC-MS/MS method for simultaneous determination of multi-class cyanobacterial and algal toxins. J. Hazard. Mater. 323:56-66.

Zhang QT, Warwick RM, McNeill CL, Widdicombe CE, Sheehan A, Widdicombe S, 2015. An unusually large phytoplankton spring bloom drives rapid changes in benthic diversity and ecosystem function. Progr. Oceanogr. 137:533-545. 